\title{
Invasive ornamental fish: a potential threat to aquatic biodiversity in peninsular India
}

\section{J.D. Marcus Knight}

Flat "L", Sri Balaji Apartments, $7^{\text {th }}$ Main Road, Dhandeeswaram, Velacherry, Chennai, Tamil Nadu 600042, India Email: jdmarcusknight@yahoo.co.in

Date of publication (online): 26 February 2010 Date of publication (print): 26 February 2010 ISSN 0974-7907 (online) | 0974-7893 (print)

\section{Editor: Neelesh Dahanukar}

\section{Manuscript details:}

Ms \# 02179

Received 10 April 2009

Final received 30 November 2009

Finally accepted 23 December 2009

Citation: Knight, J.D.M. (2010). Invasive ornamental fish: a potential threat to aquatic biodiversity in peninsular India Journal of Threatened Taxa 2(2): 700-704.

Copyright: ๑ J.D. Marcus Knight 2010. Creative Commons Attribution 3.0 Unported License. JoTT allows unrestricted use of this article in any medium for non-profit purposes, reproduction and distribution by providing adequate credit to the authors and the source of publication.

Author Detail: The author is a naturalist based in Chennai. Amongst others, his interest is in exploring the freshwater habitats and is currently documenting the diversity of freshwater fish in and around Chennai, Tamil Nadu.

Acknowledgements: I would like to thank Dr. K. Rema Devi and Dr. V. M. Sathish Kumar, Marine Biological Station, Zoological Survey of India, Santhome, Chennai for providing valuable literature which helped in drafting the paper. Thanks are also due to the anonymous reviewer for his very constructive comments.

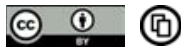

OPEN ACGESS | FREE DOWNLOAD
Abstract: Alien fish find their way into newer habitats and ecosystems opportunistically. Once in a new habitat, these species try to occupy empty niches and compete with native species. An alien species becomes invasive wherever it has a competetive advantage over native species. Ecology of aquatic invasive alien species is rather poorly understood as most attention has been on invertebrates as that which spread through ballast water. Invasive alien species of fish that have taken advantage of the aquarium trade are emerging as the most important threats to fragile aquatic habitats. Regulations to this trade are rather weak and there is a general lack of data on the ecological impact of alien fish species despite the fact that a third of the world's worst aquatic invasive species are aquarium or ornamental species.

Keywords: Amphilophus trimaculatum, Carassius auratus, invasive Alien Species, Poecilia reticulata, Pterygoplichthys multiradiatus, Pygocentrus nattereri, Osphronemus goramy, Trichogaster trichopterus, Xiphophorus helleri, X. maculatus.

Biotic homogenization, due to the long history of human migration, invasions and trade, blurs the difference between native and alien species, such that the origin of many species introduced in newer habitats and geographical areas during ancient times is uncertain (Nentwig 2007). Homogenization of flora and fauna around the world is a matter of great concern, as a number of species continue being transported by human beings around the world, and these organisms are replacing regionally unique organisms resulting in the loss of overall diversity that defines bio-geographic regions (Scott \& Helfman 2001). Homogenisation is frequently ignored; as species 'gains' are seen as 'habitat improvement'. Increase in local species diversity however is often due to range-expanding habitat generalists that invade biological communities at the expense of rare, endemic and other native species (Rooney et al. 2007). Invasive alien species (IAS) are the second major cause of extinctions of native and endemic species around the world (Wilcove et al. 1998).

Non-native fish are introduced around the world mainly for improving fisheries, sport, ornamental fish trade and bio-control of the mosquito (Bijukumar 2000). Transport of live fishes across the globe to nurture the aquarium industry has been on for at least a century. However, the recent focus on the trade as a possible means of sustainable livelihood poses a dangerous threat. The aquarium trade has not come under the scanner of environmentalists, conservationists, ecologists, and policy makers as much as trade in terrestrial endangered species (Naylor et al. 2001; Chapman et al. 2003; Padilla \& Williams 2004). The avenues from captivity to the wild include the dumping of unwanted fishes, escape from tanks and breeding farms perhaps during storms, and unchecked drainage of water containing organisms from tanks, and public aquariums (Padilla \& Williams 2004). Such organisms are usually healthy adults, and have a greater probability of surviving and reproducing in the wild.

Introduced fish frequently alter the aquatic ecology by changing water quality and also cause the extinction of native fish by predation and resource competition (Pimentel 2002). Introduced aquarium fish represent a major source of ecological destruction that may be locally alarming if ignored (Liang et al. 2006). A number of fish species also hybridize with one another in the wild diluting the wild genetic stock leading to long-term introgression of gene pools (Pimentel 2002).

\section{The Convention on Biological Diversity (CBD) and the IUCN guidelines on invasive species}

The article $8(\mathrm{~h})$ of $\mathrm{CBD}$ prescribes measures to "prevent the introduction, and control or even eradicate those alien species which threaten ecosystems, habitats or species". The International Union for the Conservation of Nature (IUCN) defines IAS, as "a species that becomes established in natural or semi natural ecosystems or habitats and can be an agent of change that threatens biological diversity". IUCN has also put forth guidelines to address four substantive concerns of the biological invasion problem. These guidelines were framed in the year 1994 to update IUCN's position 
statement on "Translocation of Living Organisms". These guidelines were adopted by the IUCN council in the year 2000 .

Customs, quarantine and other measures taken to safeguard against diseases and pests are inadequate to prevent species that threaten biodiversity from entering a country. The main aim of the IUCN guidelines is to move away from the older system that deals mainly with agriculture and human health and focus on preventing the loss of native biodiversity caused by IAS. The IUCN guidelines on IAS specifically emphasizes the following:

- improving understanding and awareness;

- strengthening the management response (including prevention, eradication and control);

- providing appropriate legal and institutional mechanisms; - enhancing knowledge and research efforts (IUCN 2000).

\section{Invasive ornamental fish in peninsular India and their ecological impacts}

Tilapias and the major carps are good examples of invasive food fishes. But there are many other species of non-native fish that have started establishing local populations throughout peninsular India thanks to the flourishing aquarium trade. Ornamental fishes ranging from the tiny guppy fish (Poecilia reticulata) to the large and aggressive Red Piranha (Pygocentrus nattereri) have been recorded in southern India (Bijukumar 2000). In addition to $P$. reticulata, ornamental fish such as Osphronemus goramy, Xiphophorus maculatus have been recorded from the Chalakudy River, a biodiversity hotspot in Kerala (Raghavan et al. 2008a,b; Krishnakumar et al. 2009).

Trichogaster trichopterus, a species of Southeast Asian gourami, commonly called the Three-spot Gourami has naturalized around Chennai (Daniels \& Rajagopal 2004; Daniels 2006) and around Vembanad Lake in Kerala (Krishnakumar et al. 2009). There is virtually no information on the ecological impacts of the Three-spot Gourami in its introduced range. The species is an opportunistic carnivore and is territorial and aggressive. According to Liao \& Liu (1989) the species was strongly suspected to be a resource competitor that caused decline in populations of the endangered Chinese Barb, Puntius semifasciolata. Being a bubble-nest brooder and an air breather, the gourami has the potential of establishing itself in stagnant waters rather rapidly. The two species of native gouramies Colisa fasciatus and Colisa lalia are much smaller. Locally, Trichogaster trichopterus and Colisa lalia tend to co-exist (Daniels 2006).

Another gourami called the Giant Gourami (Osphronemus goramy) has also been reported in peninsular India. This large-sized gourami was introduced into Chennai (Madras Presidency) in the year 1866 (Raj 1916) and other parts of peninsular India such as Maharashtra (Bombay Presidency) and Karnataka (Mysore State) as well (Bhimachar et al. 1944). It was also introduced into India to control aquatic macrophytes and is a voracious feeder (Petr 2000) feeding on plant material (Raj 1916; Bhimachar et al. 1944), insects and other fishes (Raj 1916). It has successfully established itself in the wild and has been recorded in Kerala (Raghavan et al. 2008a,b), Hyderabad (Chandrasekhar 2004) and the Adyar River in Chennai (Eric Ramanujam pers. comm.). Giant gouramies are fast growers and survive in polluted water as they are air breathers (Raj 1916). Gourami are known to carry pathogens such as the lymphocystis disease virus which can be transmitted to native fishes (Whittington \& Chong 2007).

In Chembarampakkam, a lake in the outskirts of Chennai, Lepidocephalus guntea a species of loach which was unknown in this region earlier has outnumbered the native Lepidocephalus thermalis. The non-native loach could have been brought in by the aquarium trade or by the interlinking of Krishna waters and Chennai drinking water reservoirs (Daniels \& Rajagopal 2004).

Carassius auratus commonly called the Gold Fish a popular aquarium fish has found its way into natural waters in peninsular India. C. auratus was reported from Maharashtra (Bombay) as early as 1878 but with uncertainty (Day 1878). But a more recent record of $C$. auratus from Pune, confirms this species has established itself in the wild (Rema Devi 1987). The bottom sucking feeding habits of $C$. auratus which resuspends nutrients and the stimulation of blue-green algae passing through their gut causes algal blooms which leads to fish mortality (Morgan \& Beatty 2004). They are known not only to increase turbidity and deplete aquatic vegetation thereby reducing spawning sites for native fish but also feed on eggs, larvae and adults of native fish (Richardson et al. 1995; Rowe \& Smith 2001). Gold fishes are also known to transmit pathogens and parasites to native fish (Fletcher \& Whittington 1998).

Pterygoplichthys multiradiatus has been reported from Kerala (Daniels 2006; Krishnakumar et al. 2009) and the presence of these tropical American Catfish (Loricariidae) in the Adyar River, Chennai was first reported by Eric Ramanujam (pers. comm.). I have recorded $P$. multiradiatus popularly traded as "suckers", establishing local populations in other wetlands around Chennai. The ecological effects of Pterygoplichthys sp. include disruption of aquatic food chain by overgrazing on the benthic algae and detritus, decline in abundance of native species due to competition and egg destruction, mortality of shore birds due to choking by the dorsal and pectoral spines, changes in aquatic plant communities due to substrate ploughing and tail lashing, and bank erosion caused by the nesting burrows (Hoover et al. 2004). In the U.S., where suckers are established locally, major efforts have been made to destroy the populations as they may pose a threat to native fishes. Loricariid catfishes are known for their parental care of eggs and fry, and their gluttonous algae-eating habits. They may exceed lengths of $25 \mathrm{~cm}$ as adults (Schrey 1992). Not only do these fishes with parental care ensure better survival of their young, adults too have very few predators. The bony armour on their bodies and the spines on their pectoral fins make them a difficult prey to feed on. The armour is reportedly strong enough to even damage fishing nets (Krishnakumar et al. 2009).

Another group of introduced fishes that have spread in the freshwaters of peninsular India are the tropical American livebearers. The mosquito fish (Gambusia affinis) and guppy (Poecilia reticulata) were first introduced as larvicidal fish in an effort to control malaria (Daniels 2002). P. reticulata has been recorded from freshwater habitats of Pune (Wagh \& Ghate 2003; Kharat et al. 2003), Karnataka (Krishnan et al. 2004, Rema Devi et al. 2006a,b), Kerala (Narayanan et al. 2005; Raghavan et al. 2008a,b; Krishnakumar et al. 2009), Tamil Nadu (Rema Devi et al. 1997; Rema Devi \& Raghunathan 1999; Rema Devi et al. 1999), the Eastern Ghats (Rema Devi \& Indra 2003) and the Wetern Ghats (Rajmohana \& Radhakrishnan 2009). Guppies are widely sold in the aquarium trade for their wide variety of colours. $P$. reticulata is considered a hazard to native cyprinids and killifishes in the United States and Africa due to egg predation and competition (Courtenay \& Meffe 1989) and to native damselflies in Hawaii due to larval predation (Englund 1999). Experiments prove 
Table 1. Invasive ornamental fishes in Peninsular India and their possible impacts

\begin{tabular}{|c|c|c|c|c|}
\hline & Species & Trade name & Native to & Possible impacts \\
\hline 1 & Poecilia reticulata & Guppy & South America & Resource competition, spread of pathogens, egg predation, larval predation \\
\hline 2 & Xiphophorus maculatus & Platy & South America & Resource competition, fin nipping, agressive nature, tadpole predation \\
\hline 3 & Xiphophorus helleri & Swordtail & South America & Resource competition, fin nipping, agressive nature, tadpole predation \\
\hline 4 & Trichogaster trichopterus & Three-spot Gourami & South East Asia & Opportunistic carnivore, territorial \& aggressive \\
\hline 5 & Pterygoplichthys multiradiatus & Sucker Catfish & South America & $\begin{array}{l}\text { Disrupts food chain by overgrazing, egg destruction, resource } \\
\text { competition, bank erosion, shore bird mortality, damage to fishing gear }\end{array}$ \\
\hline 6 & Osphronemus goramy & Giant Gourami & South East Asia & Resource competition, opportunistic carnivore, carry pathogens \\
\hline 7 & Amphilophus trimaculatum & Flowerhorn & South America & Predatory fish \\
\hline 8 & Pygocentrus nattereri & Red Piranha & South America & Predatory fish, fin and scale eating, mutilating other fish \\
\hline 9 & Carassius auratus & Gold Fish & East Asia & $\begin{array}{l}\text { Causing algal bloom, causing turbidity, eats eggs, larvae and adults of native } \\
\text { fish, transmits pathogens and parasites, depletes aquatic vegetation and } \\
\text { reduces spawning sites }\end{array}$ \\
\hline
\end{tabular}

that $P$. reticulata prefers other insect larvae to mosquito larvae in the presence of alternate prey (Manna 2008). It is a known carrier of trematode parasites and iridoviruses which may affect native fish populations (Leberg \& Vrijenhoek 1994; Whittington \& Chong 2007). It is known to eat the eggs of native fish species and act as a host for the parasitic nematode Camallanus cotti, and the Asian tapeworm Bothriocephalus acheilognathi in Hawaii (Eldredge 2000). Livebearers are closely related to the panchaxes that are found in peninsular India. However, the livebearers, as the name suggests, produce live young and hence multiply rather rapidly. Gambusia, a livebearer has been suspected of affecting the population of Aplocheilus lineatus in the Mula and Mutha rivers in Pune. This is possible because both are surface feeders and can compete with one another. But the ecological advantage that Gambusia has over $A$. lineatus, is that it is viviparous while the latter is oviparous (Wagh \& Ghate 2003). Moreover Gambusia and Poecilia reticulata appear to be more tolerant of pollution than the native fish (Wagh \& Ghate 2003; Karat et al. 2003).

Aquarium trade has augmented the introductions of live bearers further by adding the swordtail (Xiphophorus helleri) and the platy (Xiphophorus maculatus). X. maculatus has been recorded from Kerala (Krishnakumar et al.) and hill streams of the Western Ghats (Daniels 2003; Raghavan et al. 2008a,b) while $X$. helleri has been recorded from Pune (Kharat et al. 2003) and Kerala (Rema Devi et al. 1996). An Australian study showed swordtails, in combination with other poeciliids, displaced native rainbow fishes and blue-eyes by fin-nipping (Warburton \& Madden 2003). Similar deleterious competitive interactions have been reported from other countries following the species introduction (Goren \& Galil 2005). Courtenay et al. (1988) also suggested that aggression by introduced swordtails was responsible for the decline of the Utah sucker, Catostomus ardens, in a thermal spring in Wyoming, USA. Englund (1999) implicated swordtails and other introduced poeciliids in the decline of native damselflies in Hawaii through larval predation. IUCN, Conservation International and Nature Serve (2006) listed introduced swordtails as a major threat to an endangered amphibian, the Blue-sided Tree Frog, through tadpole predation. Whereas the mosquito fish is widespread in the plains of peninsular India, the others are locally common in the streams of the Western Ghats. Interestingly, in the Western Ghats, the guppy and platy tend to share the habitat with the equally colourful endemic barb Puntius melanampyx (Daniels 2003).

Although most of the man eating tales of the Red Piranha (Pygocentrus nattereri) have been reduced to realistic proportions (Sazima \& Machado 1990), the piranha still is a voracious predator. $P$. nattereri was brought into India illegally by the aquarium trade (Bijukumar 2000) and has found its way into the natural waters. Piranhas in non-native waters of North America triggered the use of rotenone to kill all fishes in the water bodies. A similar situation arose in peninsular India during the year 1998 (Express News Service 1998), but no steps were taken as there were no proper guidelines framed (Bijukumar 2000). Piranhas are shoaling predators which not only feed on smaller fish but also occasionally take a bite out of fins, scales and muscle of larger fish, in the process mutilating them (Sazima \& Machado 1990). As they are predators, they not only eat up small native fish but also tend to compete with the native predatory fish (Bennett et al. 1997) such as Channa striata, Wallago attu etc.

Until now only one genus of African Cichlids (Oreochromis) was known as invasive in India. However a new cichlid Amphilophus trimaculatum which belongs to a diverse group of South American cichlids formerly classified as Cichlasoma has been recorded from the "Rettai eri" in Chennai (Knight \& Rema Devi, in press). This species, a common aquarium fish widely sold as "Flowerhorn" for its Feng-shui value is a product of hybridisation between different South American cichlids classified as Cichlasoma and Amphilophus species. The Flowerhorn was bred in Malaysia during the second half of the 1990s, and exactly which South American cichlids are its ancestors is maintained a trade secret. Its origin has of late has caused a lot of speculation, and a number of theories have been put forth to resolve it. One of the theories suggests that the Flowerhorn Cichlid was artificially created in a Malaysian genetics laboratory by combining genes from a Goldfish with genes from the Trimac Cichlid (A. trimaculatum). The most plausible origin however suggests the result of hybridization between the Trimac Cichlid and other South American cichlids such as Midas Cichlid ( $A$. citrinellum), Red Devil Cichlid (A. labiatum) and Red-headed Cichlid (Vieja synspila). As with the mouth-brooding Tilapia, there are no native freshwater fishes that display similar parental care (Daniels 2006). The Flowerhorn is likely to emerge as a greater invasive than the tilapia. The Flowerhorn is known to grow to almost $30 \mathrm{~cm}$ in length; even a well grown Tilapia would not stand a chance against this marauder. As the Flowerhorn belongs to the cichlid family, it exhibits excellent parental care which ensures a high survival rate of the young ones. The Tilapia is an omnivore but the Flowerhorn is a predacious fish which eats smaller fish. It can easily destroy all the small fish in its habitat. If this fish, by chance finds its way to the Himalayan region or the Western Ghats, which is possible due to mega river linking projects the results would be disastrous, as these regions support aquatic habitats richest in diversity, harbouring 
the largest number of endemic species (Nautiyal 2005).

\section{The road ahead}

One-third of the aquatic species on the IUCN Invasive Species Specialist Group's list of the 100 worst invasive species (Lowe et al. 2000) are from aquarium or ornamental releases. At present, over 150 species of vertebrates, invertebrates, plants, and microbes (including pathogens) that have invaded natural ecosystems and have been documented, come from aquariums and ornamental aquatic culture. The vast majority of these are freshwater fish, other taxa from aquarium and ornamental releases are underestimated (Welcomme 1992). Released aquarium or ornamental species displace native species (Ceccherelli \& Cinelli 1997), and carry pathogens (Stewart 1991, Whittington \& Chong 2007).

It has been reported that 22 species of alien ornamental fish have established breeding populations in the waterways of Australia (Whittington \& Chong 2007). Not less than 300 exotic species are traded in India. There is no regulation to this trade and there is lack of data on the ecological impact of alien fish species. Some studies clearly show that there is a relationship between frequency of fish sold in aquarium stores and their introduction and establishment in freshwater habitats (Duggan et al. 2006). This is true as we can see guppies, swordtails, platy, sucker catfishes, gourami and the flowerhorn which are very popular fishes among hobbyist, have now successfully established in peninsular Indian waters. The lucrative aquarium trade will never be environmentally sustainable unless the consequences of escapees are considered. Regulations to prevent unwanted species introductions from aquarium and ornamental sources currently lack authority. A white list of native or safe alternative aquarium and ornamental species will help prevent unwanted introductions (Padilla \& Williams 2004).

Ornamental invasive fishes have been recorded from the Chalakudy River in the Western Ghats which is a biodiversity hotspot under threat. The presence of four 'habitat specialist' critically endangered species and sixteen endangered species makes this river a high priority area for implementing urgent conservation and management measures (Raghavan et al. 2008a). It is widely accepted that prevention is the most effective means of reducing the future costs of IAS. Although invasive aquarium species and ornamentals are a major concern, the guidelines, position statements and policies of the IUCN and the International Council for the Exploration of the Sea (ICES), currently lack teeth (Sandlund et al. 1999). The Convention on International Trade in Endangered Species (CITES) falls short of protecting aquatic habitats from invasions because it deals only with the trade in listed endangered and threatened species.

The aquarium trade industry is well organized, while those concerned about its environmental soundness are not. Thus, collaboration with the industry is essential for educating buyers, sellers, and the public, certifying stock, and preventing species from being released. Agencies concerned with the protection of coral reefs have had success working with aquarists through the Marine Aquarium Council to develop an international certification system for the quality and sustainability of marine aquarium species. This system of certification and best-practice guidelines must be expanded to cover wholesalers and retailers such that they trade "invasive-free" products and avoid dealing with close relatives of established invasive species. In addition, certification that aquatic ornamental cultivators and large-scale aquariums sterilize their outflows and take active steps to prevent the accidental release of species is essential. Educating both retailers and hobbyists about invasive species and the steps they can take to reduce the risk will have an immediate impact (Padilla \& Williams 2004). Unless stringent measures are taken to monitor the aquarium fish trade and the accidental release of exotic species into our waters; man-made tanks and lakes will soon emerge as breeding grounds for invasive fish that will eventually wipe out our native freshwater fishes. Indigenous fish populations can be sustained by culture and rehabilitation of endangered species taking into account the critical need to conserve the genetic diversity (Sreekantha \& Ramachandra 2005)

\section{REFERENCE}

Bennett, W.A., R.J. Currie, P.F. Wagner \& T.L. Beitinger (1997). Cold tolerance and potential overwintering of the Red-bellied Piranha Pygocentrus nattereri in the United States. Transactions of the American Fisheries Society 126(5): 841-849.

Biju Kumar, A. (2000). Exotic fishes and freshwater fish diversity. Zoos' Print Journal 15(11): 363-367.

Bhimachar, B.S., A. David \& B. Muniappa (1944). Observations on the acclimatization, nesting habits and early development of Osphronemus goramy (Lacepede). Proceedings of the Indian Science Congress 20: 88-101.

Ceccherelli, G. \& F. Cinelli (1997). Short-term effects of nutrient enrichment of the sediment and interactions between the seagrass Cymodocea nodosa and the introduced green alga Caulerpa taxifolia in a Mediterranean bay. Journal of Experimental Marine Biology and Ecology 217: 165-177.

Chandrasekhar, S.V.A. (2004). Fish fauna of Hyderabad and its environs. Zoos' Print Journal 19(7): 1530-1533

Chapman, J.W., T.W. Miller \& E.V. Coan (2003). Live seafood species as recipes for invasion. Conservation Biology 17: 1386-1395.

Courtenay, W.R. Jr., C.R. Robins, R.M. Bailey \& J.E. Deacon (1988). Records of exotic fishes from Idaho and Wyoming. Great Basin Naturalist 47: 523-526.

Courtenay, W.R. Jr. \& G.K. Meffe (1989). Small fishes in strange places: a review of introduced poeciliids, pp. 319-331. In: Meffe, G.K. \& Snelson, F.F. Jr. (eds.). Ecology and Evolution of Livebearing Fishes. Prentice Hall, Englewood Cliffs, New Jersey, USA, 416pp.

Daniels, R.J.R. (2002). Freshwater Fishes of Peninsular India. Universities Press, Hyderabad, India, 288pp.

Daniels, R.J.R. (2003). Impact of tea cultivation on anurans in the Western Ghats. Current Science 85(10): 1415.

Daniels, R.J.R. \& B. Rajagopal (2004). Fishes of Chembarampakkam Lake - a wetland in the outskirts of Chennai. Zoos' Print Journal 19(5): 1481-1483.

Daniels, R.J.R. (2006). Introduced fishes: a potential threat to the native freshwater fishes of Peninsular India. Journal of the Bombay Natural History Society 103(2\&3): 346-348.

Day, F. (1878). The Fishes of India; Being a Natural History of the Fishes Known to Inhabit the Seas and Freshwaters of India, Burma and Ceylon. William Dawson \& Sons Ltds., London, 778pp.

Duggan, I.C., C.A.M. Rixon \& H.J.M. Isaac (2006). Popularity and propagule pressure: determinants of introduction and establishment of aquarium fish. Biological Invasions 8: 377-382.

Eldredge, L.G. (2000). Numbers of Hawaiian species. Bishop Museum Occasional Papers 63(Supplement 5): 3-8.

Englund, R.A. (1999). The impacts of introduced poeciliid fish and Odonata on the endemic Megalagrion (Odonata) damselflies of Oahu Island, Hawaii. Journal of Insect Conservation 3: 225-243.

Express News Service (1998). Ministry orders en masse killing of piranhas. The Indian Express 26 September 1998.

Fletcher, A.S. \& I.D. Whittington (1998). A parasite-host checklist for Monogenea from freshwater fishes in Australia, with comments on biodiversity. Systematic Parasitology 41(3): 159-168.

Goren, M. \& B.S. Galil (2005). A review of changes in the fish assemblages of Levantine inland and marine ecosystems following the introduction of non-native fishes. Journal of Applied Ichthyology 21: 364-370. 
Hoover, J.J., K.J. Killgore \& A.F. Cofrancesco (2004). Suckermouth catfishes: threats to aquatic ecosystems of the United States? Aquatic Nuisance Species Research Programme Bulletin 04-1.

IUCN Conservation International and Nature Serve (2006). Global Amphibian Assessment. <www.globalamphibians.org>. Downloaded on 2 April 2009.

IUCN Guidelines for the Prevention of Biodiversity Loss caused by Alien Invasive Species (2000). Information paper Online: $<$ www.issg.org >. Downloaded on 3 April 2009.

Kharat, S.S., N. Dahanukar, R. Raut, \& M. Mahabaleshwarkar (2003). Long term changes in the freshwater fish fauna in the Northern Western Ghats, Pune. Current Science 84: 816-820.

Knight, J.D.M. \& K. Rema Devi (in press). On a record of Amphilophus trimaculatum (Günther) (Teleostei : Perciformes: Cichlidae) in the natural waters of Tamil Nadu, India. Journal of Bombay Natural History Society.

Krishnakumar, K., R. Raghavan, G. Prasad, A. Bijukumar, M. Sekharan, B. Pereira \& A. Ali (2009). When pets become pests exotic aquarium fishes and biological invasions in Kerala, India. Current Science 97: 474-476.

Leberg, P.L. \& R.C. Vrijenhoek (1994). Variation among desert topminnows in their susceptibility to attack by exotic parasites. Conservation Biology 8(2): 419- 424.

Krishnan, S., K. Rema Devi, T.J. Indra \& M.B. Raghunathan (2004). On a collection of fish from Bangalore and Kolar Districts, Karnataka. Records of the Zoological Survey of India 103(1-2): 143-155.

Liang, S.H., L.C. Chuang \& M.H. Chang (2006). The pet trade as a source of invasive fish in Taiwan. Taiwania 51(2): 93-98.

Liao, L.C. \& H.C. Liu (1989). Exotic aquatic species in Taiwan, pp. 101-118. In: de Silva, S.S. (ed.). Exotic Aquatic Organisms in Asia. Asian Fisheries Society, Manila, Philippines, Special Publication 3 , $154 \mathrm{pp}$.

Lowe, S., M. Browne \& S. Boudjelas (2000). 100 of the world's worst invasive alien species. IUCN/SSC Invasive Species Specialist Group, Auckland, New Zealand, 11pp

Manna, B., A. Aditya \& S. Banerjee. (2008). Vulnerability of the mosquito larvae to the guppies (Poecilia reticulata) in the presence of alternative preys. Journal of Vector Borne Diseases 45: 200206.

Morgan, D \& S. Beatty (2004). Fish fauna of the Vasse River and the colonisation by feral goldfish (Carassius auratus). Centre for Fish \& Fisheries Research, Murdoch University, Australia, 35pp.

Narayanan, S.P., T. Thapanjith \& A.P. Thomas (2005). A study on the icthyofauna of Aymanam Panchayath, in Vembanad wetland, Kerala. Zoos' Print Journal 20(9): 1980-1982.

Nautiyal, P. (2005). Taxonomic richness in the fish fauna of the Himalaya, Central Highlands and Western Ghats. International Journal of Ecology Environmental Science 31: 73-92.

Naylor, R.L., S.L. Williams \& D.R. Strong (2001). Aquaculture - a gateway for exotic species. Science 294: 1655-1656.

Nentwig, W. (ed.) (2007). Biological Invasions. Springer-Verlag, Heidelberg, Berlin, 466pp.

Padilla, D.K. \& S.L. Williams (2004). Beyond ballast water: aquarium and ornamental trades as sources of invasive species in aquatic ecosystem. Frontiers in Ecology and the Environment 2: 131-138.

Petr, T. (2000). Interactions Between Fish and Aquatic Macrophytes in Inland Waters: A Review. FAO Fisheries Technical Paper. No. 396. Rome, FAO, 185pp.

Pimentel, D. (ed.) (2002). Biological Invasions: economic and environmental costs of alien plant, animal, and microbe species. CRC Press, London, 384pp.

Raghavan, R., G. Prasad, P.H. Anvar-Ali \& B. Pereira (2008a). Exotic fish species in a global biodiversity hotspot: observations from River Chalakudy, part of Western Ghats, Kerala, India. Biological Invasions 10: 37-40.

Raghavan, R., G. Prasad, P.H. Anvar-Ali \& B. Pereira (2008b). Fish fauna of Chalakudy River, part of Western Ghats biodiversity hotspot, Kerala, India: patterns of distribution, threats and conservation needs. Biodiversity Conservation 17: 3119-3131.

Raj, B.S. (1916). Notes on the freshwater fishes of Madras. Records of the Indian Museum. 12: 249-294.

Rajmohana, K. \& C. Radhakrishnan (2009). Western Ghats - A
Hotspot of Biological Wealth. Zoological Survey of India, Kerala, India $32 \mathrm{pp}$.

Rema Devi, K. (1987). A golden variation. Black Buck 3(2):22-24

Rema Devi, K., T.J. Indra \& K.G. Emiliyamma (1996). On the fish collections from Kerala, deposited in the Southern Regional Station, Zoological Survey of India by NRM, Stockholm. Records of the Zoological Survey of India 95(3-4): 129-146.

Rema Devi, K., T.J. Indra, M.B. Raghunathan, M. Mary Bai \& M.S. Ravichandran (1997). Ichyofauna of the Tambraparni River system, Tamil Nadu. Zoos' Print 12(7): 1-2.

Rema Devi, K. \& M.B. Raghunathan (1999). Report on the Ichthyofauna of North Arcot District, Tamil Nadu. Records of the Zoological Survey of India 97(1): 163-177.

Rema Devi, K., T.J. Indra, M.B. Raghunathan \& M. Mary Bai (1999). On a collection of fish fauna from Chennai; Chengleput and Tiruvallur Districts of Tamil Nadu. Records of the Zoological Survey of India 97(Part 4): 151-166.

Rema Devi, K., \& T.J. Indra (2003). An updated checklist of Ichthyofauna of Eastern Ghats. Zoos' Print Journal 18(4): 10671070.

Rema Devi, K., T.J. Indra, S. Krishnan \& M.B. Naghunathan (2006a). Ichyofaunal diversity of Karnataka State. Proceedings of the National Conference on Wetland Biodiversity, Thrissur, pp. 42-46.

Rema Devi, K., T.J. Indra \& S. Krishnan (2006b). Fauna of Biligiri Rangasamy Temple Wildlife Sanctuary (Karnataka). Conservation Area Series 27: 263pp+20 pls.

Richardson, M. J., F.G. Whoriskey \& L.H. Roy (1995). Turbidity generation and biological impacts of an exotic fish, Carassius auratus, introduced into shallow seasonally anoxic ponds. Journal of Fish Biology 47(4): 576-585

Rooney, T.P., J. D. Olden, M.K. Leach \& D.A. Rogers (2007). Biotic homogenization and conservation prioritization. Biological Conservation 134: 447-450.

Rowe, D.K \& J.P. Smith (2001). The Role of Exotic Fish in the Loss of Macrophytes and Increased Turbidity of Lake Wainamu, Auckland. NIWA Client Report, New Zealand, 32pp.

Sandlund, O., P. Schei \& Å. Viken (1999). Invasive Species and Biodiversity Management. Kluwer Academic Publishers, Dordrecht, Netherlands, 448pp.

Schrey, W.C. (1992). Little rascals: spiny and suckermouth catfishes. Tropical Fish Hobbyist September: 18-38.

Sazima, I. \& F.A. Machado (1990). Underwater observations of piranhas in Western Brazil. Environmental Biology of Fishes 28:17-

Scott, M.C. \& J.S. Helfman (2001). Native invasions, homogenization, and the mismeasure(???) of integrity of fish assemblages. Fisheries 26: 6-15.

Sreekantha \& T.V. Ramachandra (2005). Fish diversity in Linganamakki reservoir Sharavati River. Ecology Environment and Conservation 11: 337-348.

Stewart, J.E. (1991). Symposium on the ecological and genetic implications of fish introductions 1990. Canadian Journal of Fisheries and Aquatic Sciences 48(Supplement 1): 110-117.

Wagh, G.K. \& H.V. Ghate (2003). Freshwater fish fauna of the rivers Mula and Mutha, Pune, Maharashtra. Zoos' Print Journal 18(1): 977-981.

Warburton, K. \& C. Madden (2003). Behavioural responses of two native Australian fish species (Melanotaenia duboulayi and Pseudomugil signifier) to introduced poeciliids (Gambusia holbrooki and Xiphophorus hellerit) in controlled conditions. Proceedings of the Linnean Society of New South Wales 124: 115-123.

Welcomme, R.L. (1992). A history of international introductions of inland aquatic species. ICES Journal of Marine Science Symposium 194: 3-14.

Whittington, R.J. \& R. Chong (2007). Global trade in ornamental fish from an Australian perspective: The case for revised import risk analysis and management strategies. Preventive Veterinary Medicine 81: 92-116.

Wilcove, D.S., D. Rothstein, J. Dubow, A. Phillips, \& E. Losos (1998). Quantifying threats to imperiled species in the United States. BioScience 48: 607-615. 